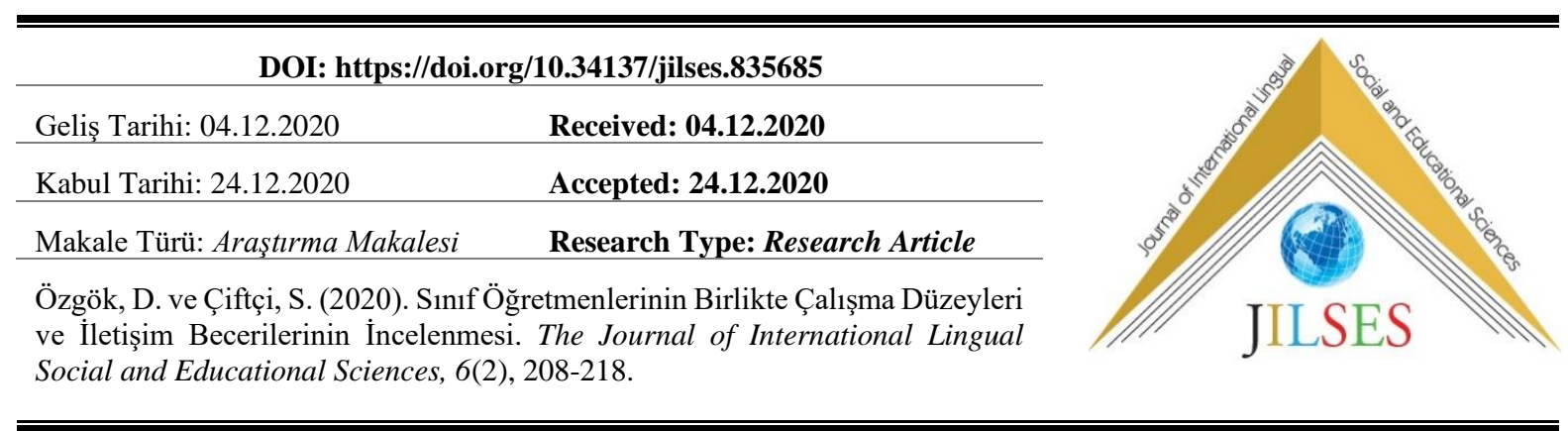

\title{
Sınıf Öğretmenlerinin Birlikte Çalışma Düzeyleri ve İletişim Becerilerinin İncelenmesi ${ }^{1}$
}

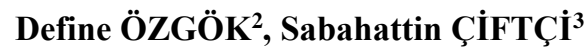

\section{Öz}

\begin{abstract}
Bu araştırmada sını öğretmenlerinin iletişim becerileri ile birlikte çalışma düzeylerinin çeşitli değişkenler açısından incelenmesi amaçlanmıştır. Araştırmanın örneklemini Van iline bağlı ilkokullarda görev yapan 192 sınıf öğretmeni oluşturmaktadır. Araştırmada toplanan sını öğretmenlerinin iletişim becerilerinin, empati, saydamlık, eşitlik, etkililik ve yeterlilik alt boyutlarının ortalamalarının ölçekten alınacak ortalama değerlerin üzerinde olduğu sonucuna ulaşılmıştır. Sinıf öğretmenlerinin iletişim becerilerine ilişkin alt boyutların, cinsiyete göre karşılaştırılmasında, empati, saydamlık, eşitlik, ve yeterlilik alt boyutları bakımından, cinsiyeti kadın olan öğretmenlerle cinsiyeti erkek olan ögretmenler arasında istatistiksel olarak kadınlar lehine anlamlı bir farklllık bulunmuştur. Etkililik alt boyutunda ise cinsiyet değişkenine göre anlamlı farklılık bulunamamıştır. Sinı öğretmenlerinin birlikte çalışma yeterliliklerine ilişskin yapılan analizlerden elde edilen bulgulara göre ögretmenlerin birlikte çalışma yeterliliklerinin yüksek olduğu sonucuna ulaşılmıştır. Sınıf öğretmenlerinin birlikte çalışma yeterlilikleri puan ortalamaları arasında ise görev süresine göre anlamlı düzeyde bir fark bulunmamıştır. Sinı öğretmenlerinin iletişim ve birlikte çalışma yeterlilikleri arasında anlamlı düzeyde olumlu bir ilişki olduğu sonucuna ulaşılmıştır.
\end{abstract}

Anahtar Kelimeler: İletişim Becerisi, Birlikte Çalışma, Sınıf Öğretmeni

\section{The Study of Working Together Levels and Communication Skills of Class Teachers}

\begin{abstract}
In this research, the skills of working together with communication skills of primary teachers are examined. The sample of the study consists of 192 primary teachers working in Van and its surrounding provinces.It was concluded that the communication skills of the primary teachers gathered in the study were above the average values of the sub-dimensions of empathy, transparency, equality, effectiveness and competence.The subdimensions of communication skills of primary teachers, in the comparison according to gender, a statistically significant difference in favour of female was found between female and male teachers in terms of the subdimensions of empathy, transparency, equality, and competence.Significant difference wasn't found in the effectiveness sub-dimension according to the gender variable. According to the findings obtained from the analyzes on the competence of working together with primary teachers, it was concluded that the competence of teachers to work together was high. There was no significant difference between the average scores of the competence of primary teachers working together according to the term of duty. It has been concluded that there is a significant positive relationship between the communication and working competencies of primary teachers.
\end{abstract}

Keywords: Communication Skills, Working Together, Primary Teacher

\footnotetext{
${ }^{1}$ Sınıf Öğretmenlerinin Birlikte Çalışma Düzeyleri Ve İletişim Becerilerinin İncelenmesi (Van İli Örneği) isimli yüksek lisans tezinden türetilmiştir.

${ }^{2}$ MEB öğretmen, define91@ hotmail.com, https://orcid.org/0000-0003-2479-4979

${ }^{3}$ Prof. Dr. Necmettin Erbakan Üniversitesi, sciftci@erbakan.edu.tr, https://orcid.org/0000-0002-5437-9867
} 


\section{Giriş}

Öğretmen, eğitim sistemi için son derece hassas bir konumda olup, sistemin temel yapı taşlarından biridir. Kalifiyedeki artış sistemin bütün unsurları için önemli olup özellikle muhatabın öğrenci olduğu düşünüldüğünde yaratıcılıklarının geliştirilmesi ve üretkenliklerinin devamlılığ için elzemdir. Bunu sağlamak içinse sistemin unsurlarının her birinin niteliğinin iyileştirilmesi ve güncellenerek çağdaş bir düzeye ulaştırılması gerekir: $\mathrm{Bu}$, çevresel şartların iyileştirilmesinden öğrenme ortam ve olanaklarının geliştirilmesine, iyi bir idare mekanizmasının işletilmesinden öğrencilerin güdülenerek sürece hazır hale getirilmelerine dek geniş bir yelpazeyi kapsar. $\mathrm{Bu}$ unsurlardan herhangi birinin eksikliği veya noksanlığı bütünün başarıya ulaşmasını ve nihai sonucu etkiler. Söz konusu verimliliğin sağlanması için çok boyutlu bir düşünme davranışı geliştirilmelidir. Sistemin bütününü iyileştirecek bu düşünme biçimini öncelikle öğretmen içselleştirmiş olmalıdır (İlhan, 2004). Okul, eğitim olgusunun nihai sonucu olarak davranış kazandırma ve/veya mevcut alışkanlık ve davranışları değiştirmeyi hedefleyen özel çevreler olmaları sebebiyle diğer kurumlardan farklı değerlendirilmelidir. Öğretmenlerin belirli bir amaç doğrultusunda birlikte hareket ederek çalıştıkları düşünüldüğünde ve kurum kaynaklarını beraber kullandıkları dikkate alındığında ortaya konan edim ve tutumların tutarlı, etkili ve uyumlu olmaları beklenir (Arslan ve Sünbül, 2006). Ancak bu sayede okul içerisinde ortaya konan müfredat, nitelikli öğretmen ve iyi bir idarenin varlığı anlam kazanacak olup; 'girdisi ve çıktısı insan olan' okulda yürütülen çalışmalar ve kullanılan kaynakların verimliliği sağlanmış olacaktır.

Bir örgütte sorunları farklı açılardan ele almak çalışanların çok daha katılımcı olmalarına imkân tanımakla kalmaz üretkenliklerinin ve yeni bir şey ortaya koyma yetilerini artırıp karşıllklı iletişimin güçlenmesini ve deneyimlerin paylaşılmasına da olanak sağlar. Bu sebeple örgütlerde üretkenliğin kaynağı olarak birlikte çalışma fikri öne çıkar ve destek görür. Bunun için bir örgüt olarak okullar da bu kapsamda değerlendirilmeli; birlikte çalışma düşüncesi teşvik edilmelidir (Çiftçi, Meydan, Koçyiğit ve Kayıll, 2011). Bu söylenenler idealde her ne kadar mümkünmüş gibi görünse de sadece birlikte çalışmanın kendi iç dinamiklerinden kaynaklanan pek çok sorunla karşılaşılabileceği göz önünde bulundurulmalıdır. Çünkü birlikte çalışma dinamiği hem hazırbulunuşluk açısından öğretmen ve idarecilerin hem de insan faktörü devreye girdiği için bütün katılımcıların bu konuda istekli, aynı zamanda değişim ve gelişmeye açık bir kişilik yapısı ortaya koymalarını gerektirir. Bunun için de en önemli şey kişiler arasındaki iletişimin niteliği ve kalitesidir.

Bir birey olarak öğretmenin iletişiminin ilerleyip gelişme kaydetmesi için yakın çevresiyle olan ilişkileri, aile içi fikir alışverişleri ve öğrencileriyle olan diyaloglarının iyi olmasına bağlıdır. Öğrencinin karakter ve şahsiyet gelişiminden bir birey olarak sağlıklı bir iletişim davranışı geliştirmeye kadar pek çok zihinsel ve bilişsel gelişim aşaması için öğretmenin iletişim kurma yetisi oldukça etkilidir. Bir öğretmen hem akademik anlamda aktarımda bulunurken hem de derslerin dışında öğrencilere olumlu anlamda tesir edebilmesi etkili bir iletişim yetisine ihtiyaç duyar. Hem bilgi ve düşüncenin iletilebilmesi hem de öğrencinin derse katılımını ve öğrenme istekliliğini artırmak için doğru soru sorulabilmesi için kendisini etkili bir biçimde ifade edebilmesi; sorulan soruları anlayarak öğrencinin fikir ve bakış açısını kavrayabilmesi için iyi bir dinleyici olması beklenir (Çam,1999). Bütün bu niteliklerin yeterli düzeyde olduğu öğretmenlerin hem mesleki anlamda hem de insan ilişkilerinde daha başarılı olacağı; hem öğrencilerle hem de meslektaşları ve amirleriyle geliştireceği bu olumlu ilişkiler sayesinde kurumsal başarıya da olumlu yönde katkı sağlayacağı söylenebilir. Buradan hareketle bu araştırmada sınıf öğretmenlerinin birlikte çalışma düzeyleri ve iletişim becerilerinin incelenmesi amaçlanmıştır. Bu amaç doğrultusunda aşağıdaki sorulara cevap aranmıştır.

1. Sınıf öğretmenlerinin birlikte çalışma yeterlilikleri ve iletişim becerileri ne düzeydedir?

2. Sınıf öğretmenlerinin birlikte çalışma yeterlilikleri ve iletişim becerileri cinsiyet değişkenine göre farkl11ık göstermekte midir?

3. Sınıf öğretmenlerinin birlikte çalışma yeterlilikleri ve iletişim becerileri öğretmenlerin görev yaptıkları yer değişkenine göre farkl1lık göstermekte midir?

4. Sınıf öğretmenlerinin birlikte çalışma yeterlilikleri ve iletişim becerileri öğretmenlerin mesleki kıdem değişkenine göre farklılık göstermekte midir?

5. Sınıf öğretmenlerinin birlikte çalışma yeterlikleri ile iletişim becerileri arasında anlamlı bir ilişki var midir?

\section{Yöntem}

Yöntem bölümünde araştırmanın modeli, evren ve örneklemi, veri toplama araçları ve verilerin analizleri yer almaktadır. 


\section{Araştırmanın Modeli}

Araştırma tarama modelinde betimsel bir çalışmadır. Karasar'a (2011) göre tarama modelli çalışmalar, geçmişte ya da halen var olan bir durumu var olduğu şekliyle betimlemeyi amaçlar. İlişkisel tarama modelleri ise iki veya daha fazla değişken arasında birlikte değişim varlığını veya derecesini belirlemeyi amaçlayan araştırma modelleridir. Bu araştırma sınıf öğretmenlerinin birlikte çalışma düzeyleri ve iletişim becerilerinin incelendiği bir çalışmadır.

\section{Çalışma Grubu}

Araştırmanın örneklemini Van iline bağlı ilkokullarda görev yapan 192 sınıf öğretmeni oluşturmuştur. Öğretmenlerin 103'ü erkek 89'u ise kadın ögrretmendir. Öğretmenlerin 156'sı köyde görev yaparken 36'sı kent merkezinde görev yapmaktadır. Araştırmanın örneklemi oluşturulurken kolay ulaşılabilir örneklem seçilmiştir. Kolay ulaşılabilir veya elverişli örnekleme tamamen mevcut olan, ulaşması hızlı ve kolay olan öğelere dayanır (Patton, 2005, akt. Baltac1, 2018).

\section{Verilerin Toplanması}

Öğretmenlerin Birlikte Çalışma Ölçeği: Ölçeğin geliştirilme sürecinde ölçeğin içerisindeki maddeler için aritmetik ortalama ve standart sapma hesaplanmış madde kalan ve madde toplam analizleri gerçekleştirilmiş. Ölçeğin geçerliği için faktör analizi güvenirliği için Cronbach Alfa teknikleri kullanılmıştır. Ölçeğin Cronbach Alfa güvenirlik katsayısı $\mathrm{r}=.88,65^{\prime}$ dir. Ölçeğin içerisindeki her bir maddenin geçerliğinin ölçütü olarak madde-test korelasyon (ıtem-total) katsayısı kullanılmıştır. Hesaplanan Person Momentler Çarpım Korelasyon katsayıları 0,45 ile 0,66 arasında değişmektedir. Bu bulgular ölçeğin ve içerisindeki her bir maddenin ölçeğin ölçmeyi amaçladığı özelliklerle aynı yönde ve tutarlı bir dağılıma sahip olduğunu göstermektedir (Arslan ve Sünbül, 2006)

Öğretmen İletişim Becerileri Ölçeği (ÖIBBÖ) : Çetinkanat (1997) tarafından geçerlik ve güvenirlik çalışması yapılan ölçeğin Cronbach Alfa güvenirlik katsayısı $r=.81$ 'dir. Ölçeğin empati, saydamlık, eşitlik, etkililik ve yeterlilik olmak üzere beş alt boyutu bulunmaktadır. Ölçek toplam 44 sorudan oluşmaktadır. Ölçeğin empati boyutunda 10 , saydamlık boyutunda 10 , eşitlik boyutunda 10 , etkililik boyutunda 10 ve yeterlilik boyutunda ise 4 madde yer almaktadır. Ölçekte yer alan maddeler $1=$ hiçbir zaman ve $6=$ her zaman olmak üzere 6'l dereceleme ile cevaplandırılmaktadır. Ancak yüksek puanlar iletişim becerileri açısından yeterlilik düzeyini ifade etmektedir (Bulut, 2003). ÖİBÖ’nün alt boyutları aşağıda açıklanmıştır.

Empati:Empati, eğitimcinin, kendini öğrencinin yerine koyarak, onu dinlemeye, anlamaya çalışması ve bunun sonucunda tepki göstermesini ifade eder.

Saydamlık:Saydamlık bireyin olduğugibi görünmesi, başka bireylerle arasına rolünden kaynaklanan farklı bir imaj sergilemeye çalı̧̧madan doğal olması demektir.

Eşitlik:Eğitimci ve öğrenci arasındaki ilişkinin eşit, aralarında rol ve statüden kaynaklanan psikolojik bir uzaklık konmadan olumlu bir öğrenme atmosferi yaratabilecek düzeyde olmalısıdır.

Etkililik:Eğitimcinin öğrenmeyi gerçekleştirmesi,öğrenmenin gerçekleşip gerçekleşmediğini kontrol etmesini kapsar.

Yeterlik:Eğitimcinin kendi alanında iyi yetişmiş olması, bilgilerini sunmadaki yeterliliği öğretmen iletişim becerileri arasında önemli bir boyuttur(Çetinkanat, 1997).

\section{Verilerin analizi ve yorumlanması}

Araştırmada elde edilen bulgular değerlendirilirken, istatistiksel analizler için SPSS programı kullanılmıştır. Birlikte Çalışma Yeterlilikleri ve İletişim Becerileri ölçeklerinden alınan puanların öğretmenlerin cinsiyet ve görev yaptıkları yer değişkenine göre farklılık durumunu belirlemek amacıyla Bağımsız Örneklemler $t$ testi kullanılmıştır. Birlikte Çalışma Yeterlilikleri ve İletişim Becerileri ölçeklerinden alınan puanların mesleki kıdeme göre farklllık durumunu belirlemek için Kruskal Wallis Testi ve Mann Whitney U Testi analizi kullanılmıştır. Birlikte Çalışma Yeterlilikleri ve İletişim Becerileri arasındaki ilişkiyi belirlemek için Pearson korelasyon analizi kullanılmıştır.

\section{Bulgular ve Yorumlar}

\section{Araştırmanın birinci alt problemine ilişkin bulgular;}

Araştırmanın birinci alt probleminde sınıf öğretmenlerinin birlikte çalışma yeterlilikleri ve iletişim becerileri ne düzeydedir? Sorusuna cevap aranmıştır. Yapılan analizlerin sonuçları Tablo. 1'de gösterilmiştir. 
Tablo 1: Değişkenlere ilişkin tanımlayıcı istatistikler

\begin{tabular}{cccccc}
\hline & $\mathbf{N}$ & $\begin{array}{c}\text { Minimum } \\
\text { değer }\end{array}$ & $\begin{array}{c}\text { Maksimum } \\
\text { değer }\end{array}$ & Ortalama & Standart Sapma \\
\hline Empati & $\mathbf{1 9 2}$ & 21.00 & 50.00 & 38.04 & 5.99 \\
Saydamlık & $\mathbf{1 9 2}$ & 19.00 & 50.00 & 37.53 & 6.31 \\
Eşitlik & $\mathbf{1 9 1}$ & 22.00 & 50.00 & 38.16 & 6.17 \\
Etkililik & $\mathbf{1 9 2}$ & 22.00 & 46.00 & 35.56 & 4.44 \\
Yeterlilik & $\mathbf{1 9 2}$ & 9.00 & 20.00 & 15.76 & 2.31 \\
$\begin{array}{c}\text { Birlikte çalısma } \\
\text { yeterlikleri }\end{array}$ & $\mathbf{1 9 2}$ & 1.00 & 36.00 & 26.49 & 6.47 \\
\hline
\end{tabular}

Değişkenlere ilişkin tanımlayıcı istatistikler incelendiğinde; empati (Ort.=38.04, Ss=5.99), saydamlık (Ort. $=37.53$, $\mathrm{Ss}=6.31)$, eşitlik $($ Ort.=38.16, Ss=6.17), etkililik $($ Ort.=35.56, Ss=4.44), yeterlilik $($ Ort.=15.76, Ss=2.31), birlikte çalışma yeterlilikleri (Ort.=26.49, Ss=2.31), ortalama ve standart sapma değerlerine sahip olduğu görülmektedir.

\section{Araştırmanın ikinci alt problemine ilişkin bulgular;}

Araştırmanın ikinci alt probleminde sınıf öğretmenlerinin birlikte çalışma yeterlilikleri ve iletişim becerileri cinsiyet değişkenine göre farklılık göstermekte midir? Sorusuna cevap aranmıştır. Yapılan analizlerin sonuçları Tablo. 2'de gösterilmiştir.

Tablo 2: Cinsiyete göre iletişim becerileri ve birlikte çalışma yeterlilikleri puan ortalamalarına ilişkin t testi sonucu

\begin{tabular}{|c|c|c|c|c|c|}
\hline & Cinsiyet & $\mathbf{N}$ & Ortalama & $\mathbf{T}$ & $\mathbf{p}$ \\
\hline \multirow[t]{2}{*}{ Empati } & Erkek & 103 & 35.99 & \multirow{2}{*}{-5.46} & \multirow{2}{*}{$.00 * *$} \\
\hline & Kadın & 89 & 40.40 & & \\
\hline \multirow[t]{2}{*}{ Saydamlık } & Erkek & 103 & 34.92 & \multirow{2}{*}{-6.85} & \multirow{2}{*}{$.00^{* * *}$} \\
\hline & Kadın & 89 & 40.54 & & \\
\hline \multirow[t]{2}{*}{ Eşitlik } & Erkek & 102 & 35.61 & \multirow{2}{*}{-6.82} & \multirow{2}{*}{$.00 * *$} \\
\hline & Kadın & 89 & 41.09 & & \\
\hline \multirow[t]{2}{*}{ Etkililik } & Erkek & 103 & 35.71 & \multirow[t]{2}{*}{.52} & \multirow[t]{2}{*}{.602} \\
\hline & Kadın & 89 & 35.38 & & \\
\hline \multirow[t]{2}{*}{ Yeterlilik } & Erkek & 103 & 14.92 & \multirow[t]{2}{*}{-5.84} & \multirow[t]{2}{*}{$.00 * *$} \\
\hline & Kadın & 89 & 16.73 & & \\
\hline \multirow[t]{2}{*}{ Birlikte çalışma yeterlikleri } & Erkek & 103 & 26.11 & \multirow{2}{*}{-.88} & \multirow{2}{*}{.38} \\
\hline & Kadın & 89 & 26.93 & & \\
\hline
\end{tabular}

$* * \mathbf{p}<.01, * \mathbf{p . 0 5}$

Tablo 2 incelendiğinde; empati, saydamlık, eşitlik, yeterlilik puan ortalamalarında cinsiyete göre anlamlı bir fark olduğu görülmektedir. Etkililik ve birlikte çalışma yeterlilikleri puan ortalamaları arasında ise cinsiyete göre anlamlı düzeyde bir fark yoktur. Aralarında anlamlı düzeyde fark bulunan bütün boyutlarda kadın öğretmenlerin erkek öğretmenlerden daha yüksek puan ortalamasına sahip olduğu görülmektedir.

\section{Araştırmanın üçüncü alt problemine ilişkin bulgular;}

Araştırmanın üçüncü alt probleminde sınıf öğretmenlerinin birlikte çalışma yeterlilikleri ve iletişim becerileri öğretmenlerin görev yaptıkları yer değişkenine göre farklılık göstermekte midir? Sorusuna cevap aranmıştır. Yapılan analizlerin sonuçları Tablo. 3'de gösterilmiştir. 
Tablo 3: Görev yapılan yere göre iletişim becerileri ve birlikte çalışma yeterlilikleri puan ortalamalarına ilişkin $\mathrm{t}$ testi sonucu

\begin{tabular}{llcccc}
\hline & & $\mathbf{N}$ & Ortalama & $\mathbf{z}$ & $\mathbf{p}$ \\
\hline Empati & Köy & 156 & 38.23 & -.791 & .429 \\
& Merkez & 36 & 37.19 & & \\
\hline Saydamlık & Köy & 156 & 37.69 & -.610 & .542 \\
\hline Eşitlik & Merkez & 36 & 36.77 & & \\
\hline Köy & 156 & 38.60 & -1.634 & .102 \\
\hline Metkililik & Köy & 36 & 36.27 & & \\
\hline Meterlilik & Merkez & 156 & 35.79 & -1.501 & .133 \\
& Köy & 36 & 34.55 & & \\
\hline Birlikte çalışma & Köy & 156 & 15.89 & -1.345 & .179 \\
yeterlikleri & Merkez & 36 & 15.19 & & \\
\hline & Merkez & 156 & 27.37 & -3.995 & $.00 * *$ \\
\hline
\end{tabular}

$* * \mathbf{p}<.01, * \mathbf{p . 0 5}$

Tablo 3 incelendiğinde; empati, saydamlık, eşitlik, etkililik, yeterlilik puan ortalamalarında görev yapılan yere göre anlamlı düzeyde bir fark olmadığı ortaya çıkmaktadır. Birlikte çalışma yeterlilikleri puan ortalamaları arasında ise görev yapılan yere göre anlamlı düzeyde bir fark bulunmuştur. Birlikte çalışma yeterlilikleri puan ortalamaları incelendiğinde; köy de çalıştığını söyleyen öğretmenlerin merkezde çalışan öğretmenlere göre birlikte çalışma yeterlilik puan ortalamalarının daha yüksek olduğu görülmektedir.

\section{Araştırmanın dördüncü alt problemine ilişkin bulgular;}

Araştırmanın dördüncü alt probleminde sınıf öğretmenlerinin birlikte çalışma yeterlilikleri ve iletişim becerileri öğretmenlerin mesleki kıdem değişkenine göre farklılık göstermekte midir? Sorusuna cevap aranmıştır. Yapılan analizlerin sonuçları Tablo. 4'de gösterilmiştir. 
Tablo 4: Görev süresi değişkenine göre iletişim becerileri ve birlikte çalışma yeterlilikleri puan ortalamalarına ilişkin Kruskal Wallis ve Mann Whitney U sonuçları

\begin{tabular}{|c|c|c|c|c|c|}
\hline & Görev yüresi & $\overline{\mathbf{N}}$ & Ortalama & p & \\
\hline \multirow{4}{*}{ Empati } & $1-5 \mathrm{y} 1 \mathrm{l}$ & 118 & 36.7458 & \multirow{4}{*}{$.00 * *$} & \multirow{4}{*}{$\begin{array}{l}1<2 \\
3<4 \\
1<4\end{array}$} \\
\hline & 6-10 y1l & 23 & 40.0000 & & \\
\hline & $11-20 \mathrm{y} 1 \mathrm{l}$ & 34 & 37.8472 & & \\
\hline & 20 yıl ve üzeri & 16 & 40.4375 & & \\
\hline \multirow{4}{*}{ Saydamlık } & $1-5$ y1l & 118 & 35.9576 & \multirow{4}{*}{$.00 * *$} & \multirow{4}{*}{$\begin{array}{l}1<2 \\
1<3 \\
1<4\end{array}$} \\
\hline & 6-10 y1l & 23 & 39.3913 & & \\
\hline & $11-20 \mathrm{y} 1 \mathrm{l}$ & 34 & 40.8824 & & \\
\hline & 20 yıl ve üzeri & 16 & 36.4643 & & \\
\hline \multirow{4}{*}{ Eşitlik } & $1-5 \mathrm{y} 1 \mathrm{l}$ & 118 & 37.0254 & \multirow{4}{*}{$.00 * *$} & \multirow{4}{*}{$1<3$} \\
\hline & 6-10 y1l & 23 & 38.5217 & & \\
\hline & $11-20 \mathrm{y} 1 \mathrm{l}$ & 34 & 41.1176 & & \\
\hline & 20 yıl ve üzeri & 16 & 39.7500 & & \\
\hline \multirow{4}{*}{ Etkililik } & $1-5 \mathrm{y} 1 \mathrm{l}$ & 118 & 35.8220 & \multirow{4}{*}{.72} & \\
\hline & 6-10 y1l & 23 & 35.0000 & & \\
\hline & $11-20 \mathrm{y} 1 \mathrm{l}$ & 34 & 35.4706 & & \\
\hline & 20 yıl ve üzeri & 16 & 34.6875 & & \\
\hline \multirow{4}{*}{ Yeterlilik } & $1-5$ y1l & 118 & 15.2966 & \multirow{4}{*}{$.00 * *$} & \multirow{4}{*}{$\begin{array}{l}1<2 \\
1<3\end{array}$} \\
\hline & $6-10 \mathrm{y} 1 \mathrm{l}$ & 23 & 15.2966 & & \\
\hline & $11-20$ y1l & 34 & 16.7826 & & \\
\hline & 20 yıl ve üzeri & 16 & 16.5000 & & \\
\hline \multirow{4}{*}{$\begin{array}{c}\text { Birlikte çalışma } \\
\text { yeterlikleri }\end{array}$} & $1-5$ y1l & 118 & 27.1102 & \multirow{4}{*}{.32} & \\
\hline & 6-10 y1l & 23 & 20.7378 & & \\
\hline & $11-20 \mathrm{y} 1 \mathrm{l}$ & 34 & 25.5882 & & \\
\hline & 20 yıl ve üzeri & 16 & 27.5625 & & \\
\hline
\end{tabular}

Tablo 4 incelendiğinde; empati, saydamlık, eşitlik, yeterlilik puan ortalamalarında görev süresi değişkenine göre anlamlı bir fark olduğu görülmektedir. Etkililik ve birlikte çalışma yeterlilikleri puan ortalamaları arasında ise görev süresine göre anlamlı düzeyde bir fark bulunmamıştır. Empati alt boyutu puan ortalamaları arasındaki farka ilişkin Mann Whitney U sonuçlarına göre 6-10 yıl görev süresi olanların 1-5 yıl süresi olanlara göre empati puan ortalaması anlamlı düzeyde yüksektir. Ayrıca 20 yıl ve üzeri görev süresi olanların empati puan ortalaması 1- 5 yıl olan öğretmenler ile 11-20 yıl olan öğretmenlerin puan ortalamalarına göre anlamlı düzeyde yüksektir.

Saydamlık alt boyut açısından incelendiğinde Mann Whitney U sonuçlarına göre 6-10 yıl görev süresi olanların 15 yıl süresi olanlara göre saydamlık puan ortalaması anlamlı düzeyde yüksektir. Ayrıca 20 yıl ve üzeri görev süresi olanların saydamlık puan ortalaması 1-5 yıl olan öğretmenlere göre, 11-20 yıl görev süresi olan öğretmenlerin saydamlık puan ortalaması 1-5 yıl olan öğretmenlerin puan ortalamalarına göre anlamlı düzeyde yüksektir.

Eşitlik alt boyutunda ise sadece 11-20 yıl görev süresi olan öğretmenlerin 1-5 yıl görev süresi olan öğretmenlere göre anlamlı düzeyde yüksek puan ortalamasına sahip olduğu bulunmuştur. Yeterlilik alt boyutu açısından 
bakıldığında 6-10 yıl ve 11-20 yıl görev süresine sahip öğretmenlerin puan ortalamalarının 1-5 y1l görev süresine sahip öğretmenlerin puan ortalamalarına göre anlamlı düzeyde yüksek olduğu görülmektedir.

\section{Araștırmanın beşinci alt problemine ilișkin bulgular;}

Araştırmanın beşinci alt probleminde Sınıf öğretmenlerinin birlikte çalışma yeterlikleri ile iletişim becerileri arasında anlamlı bir ilişki var mıdır? Sorusuna cevap aranmıştır. Yapılan analizlerin sonuçları Tablo. 5'de gösterilmiştir.

\begin{tabular}{|c|c|c|c|c|c|c|}
\hline Değişkenler & $\mathbf{1}$ & 2 & 3 & 4 & 5 & $\overline{6}$ \\
\hline 1. Empati & - & & & & & \\
\hline 2. Saydamlık & $.80^{* *}$ & - & & & & \\
\hline 3. Esitlik & $.86^{* *}$ & $.78^{* *}$ & - & & & \\
\hline 4. Etkililik & $.52^{* *}$ & $.49^{* *}$ & $.45^{* *}$ & - & & \\
\hline 5. Yeterlilik & $.81^{* *}$ & $.75^{* *}$ & $.83^{* *}$ & $.41^{* *}$ & - & \\
\hline $\begin{array}{l}\text { 6. Birlikte çalışma } \\
\text { yeterlikleri }\end{array}$ & $.14^{*}$ & .13 & $.21^{* *}$ & $.17^{*}$ & $.16^{*}$ & - \\
\hline
\end{tabular}

Tablo 5 incelendiğinde; empati ile saydamlık $(\mathrm{r}=.80, \mathrm{p}<.01)$, eşitlik $(\mathrm{r}=.86, \mathrm{p}<.01)$, etkililik $(\mathrm{r}=.52$, $\mathrm{p}<.01)$, yeterlilik $(\mathrm{r}=.81, \mathrm{p}<.01)$ ve birlikte çalışma yeterlilikleri $(\mathrm{r}=.14, \mathrm{p}<.05)$ arasında anlamlı düzeyde olumlu bir ilişki olduğu görülmektedir. Saydamlık ile eşitlik $(r=.78, p<.01)$, etkililik $(r=.49, p<.01)$, yeterlilik $(r=.75, p<.01)$ arasında anlamlı düzeyde olumlu bir ilişki olduğu bulunmuştur. Eşitlik alt boyutu ile etkililik $(r=.45, p<.01)$, yeterlik $(\mathrm{r}=.83, \mathrm{p}<.01)$ ve birlikte çalışma yeterlilikleri $(\mathrm{r}=.21, \mathrm{p}<.01)$ arasında anlamlı düzeyde olumlu bir ilişki olduğu görülmektedir. Bununla birlikte etkililik alt boyutu ile yeterlilik $(\mathrm{r}=.41, \mathrm{p}<.01)$ ve birlikte çalışma yeterlilikleri $(\mathrm{r}=.17, \mathrm{p}<.05)$ arasında anlamlı düzeyde olumlu bir ilişki olduğu görülmektedir. yeterlilik alt boyutu ile birlikte çalışma yeterlilikleri $(\mathrm{r}=.16, \mathrm{p}<.05)$ arasında ise anlamlı düzeyde olumlu bir ilişki olduğu ortaya çıkmıştır.

\begin{tabular}{lcccccrr}
\hline Tablo 6: Birlikte Çalışma Yeterlilikleri Üzerinde İletişim Becerilerinin Etkisi \\
\hline & $\mathbf{R}$ & $\mathbf{R}^{\mathbf{2}}$ & $\boldsymbol{R}^{2} \boldsymbol{c h}$ & $\boldsymbol{B}$ & $\boldsymbol{\beta}$ & \multicolumn{1}{c}{$\mathbf{t}$} & \multicolumn{1}{c}{} \\
\hline Sabit & $\mathbf{. 2 6}$ & $\mathbf{. 0 7}$ & $\mathbf{. 0 4}$ & 15.23 & & 3.69 & $.00 * *$ \\
Empati & & & & -.22 & -.21 & -1.26 & .21 \\
Saydamlık & & & & -.06 & -.06 & -.44 & .66 \\
Eşitlik & & & & .39 & .37 & 2.35 & $.02 *$ \\
Etkililik & & & & .18 & .13 & 1.51 & .13 \\
Yeterlilik & & & & .02 & .01 & .06 & .95 \\
\hline
\end{tabular}

Birlikte çalışma yeterliliklerini, iletişim becerilerinin anlamlı düzeyde açıklayıp açıklamadığına ilişkin oluşturulan model sonucunda; iletişim becerilerinin etkisinin anlamlı düzeyde $\left(\mathrm{R}^{2}=.07, \mathrm{p}<.01\right.$ ) olduğu görülmektedir. $\mathrm{Bu}$ sonuç iletişim becerilerinin, birlikte çalışma yeterliliklerindeki varyansın \% 7'sini açıkladığını göstermektedir. Alt boyutlar incelendiğinde sadece eşitlik alt boyutunun $(\beta=-.37)$ özgün etkisinin bulunduğunu göstermektedir.

\section{Sonuç ve Tartışma}

Araştırmada toplanan verilerin analizlerinden elde edilen bulgulara göre sınıf öğretmenlerinin iletişim becerilerinin, empati, saydamlık, eşitlik, etkililik ve yeterlilik alt boyutlarının ortalamalarının ölçekten alınacak ortalama değerlerin üzerinde olduğu sonucuna ulaşılmıştır. Güney ve Şara (2015) ile Ocak ve Erşen (2011) tarafından yapılan çalışmalarda öğretmen ve öğretmen adaylarının iletişim becerilerinin yüksek düzeyde olduğu sonuçlarına ulaşmışlardır. Bu sonuçlar çalışmadan elde dilen sonuçlarla paralellik göstermektedir.

Sınıf öğretmenlerinin iletişim becerilerine ilişkin alt boyutların, cinsiyete göre karşılaştırılmasında, empati, saydamlık, eşitlik, ve yeterlilik alt boyutları bakımından, cinsiyeti kadın olan öğretmenlerle cinsiyeti erkek olan öğretmenler arasında istatistiksel olarak kadınlar lehine anlamlı bir farklılık bulunmuştur. Etkililik alt boyutunda ise cinsiyet değişkenine göre anlamlı farklılık bulunamamıştır.

Bozkurt Bulut (2003), Çiftçi ve Taşkaya (2010), Güney ve Şara ( 2015), Nacar (2010), Ocak ve Erşen (2011) yaptıkları çalışmalarda öğretmenlerin iletişim becerilerinin kadın öğretmenler lehine anlamlı farklılık gösterdiğini bulmuşlardır. Bu çalışmalardan elde edilen sonuçlar çalışmadan elde edilen sonuçlarla paralellik göstermektedir. 
Bu sonuçlardan hareketle kadın öğretmenlerin iletişim becerilerinin erkek öğretmenlere göre daha gelişmiş olduğu söylenebilir.

Levent (2011) ise iletişim becerilerine ilișkin alt boyutların, cinsiyete göre karşılaştırılmasında, empati, saydamlık, eşitlik, etkililik ve yeterlilik alt boyutları bakımından, cinsiyeti kadın olan öğretmenlerle cinsiyeti erkek olan öğretmenler arasında istatistiksel olarak anlamlı bir farklılık bulunamamıştır.

Sınıf öğretmenlerinin birlikte çalışma yeterliliklerine ilişkin yapılan analizlerden elde edilen bulgulara göre öğretmenlerin birlikte çalışma yeterliliklerinin yüksek olduğu sonucuna ulaşılmıştır. Bu sonuçlara göre sınıf öğretmenlerinin birlikte çalışmalar yaptıkları söylenebilir.

Satman (2013) tarafından yapılan araştırmada, sınıf öğretmenlerinin birlikte çalışma yeterlilikleri cinsiyet değişkenine göre anlamlı farklılık göstermemektedir. Yapılan çalışmada öğretmenlerin ekip çalışmasına yönelik tutumları kadın öğretmenler lehine daha yüksek bulunmuştur. Yapılan bu çalışma da kadın öğretmenlerin birlikte çalışma ortalamaları erkek öğretmenlerin ortalamasından yüksek çıkmıştır.

Arslan ve Sünbül (2006), Aydın ve Sezgin Nartgün (2015), Duman Göçen ve Duran (2013) yaptıkları çalışmalarda öğretmenlerin birlikte çalışma yeterlilikleri cinsiyete göre farklılaşmadığı sonuçlarına ulaşmışlardır. Bu sonuçlar çalışmadan elde edilen sonuçlarla paralellik göstermektedir.

Sınıf öğretmenlerinin iletişim becerilerine ilişkin alt boyutların, görev yapılan yer değişkenine göre karşılaştırılmasında, empati, saydamlık, eşitlik, etkililik ve yeterlilik alt boyutları bakımından, anlamlı bir farklılık bulunmuştur. Nacar (2010) yaptığı çalışmada öğretmenlerin iletişim becerileri ölçeğinden aldıkları puan ortalamalarının görev yaptıkları okulun sosyo ekonomik düzeyine göre iletişim becerilerinin farklılaştığı sonucuna ulaşmıştır. Bu sonuçlar çalışmadan elde edilen sonuçlarla paralellik göstermektedir.

Sınıf öğretmenlerinin birlikte çalışma yeterlilikleri görev yapılan yer değişkenine göre köyde görev yapan öğretmenler lehine anlamlı farklılık göstermektedir. Bu sonuç köyde görev yapan öğretmenlerin yardım alabilecek kişi ve imkanlarının az olması nedeniyle öğretmenlerin birlikte çalışmak zorunda kalmalarından kaynaklanıyor olabilir. Arslan ve Sünbül (2006) yaptıkları çalışmada öğretmenlerin birlikte çalışma yeterlilikleri görev yaptıkları yer değişkenine göre anlamlı farklılık göstermektedir. Bu sonuç çalışmadan elde edilen sonuçla paralellik göstermektedir. Bunun yanı sıra Aydın ve Sezgin Nartgün (2015) yaptıkları çalışmada öğretmenlerin çalıştıkları yerleşim yeri değişkeni istatistiksel olarak anlamlı bir farklılık oluşturmamıştır.

Sınıf öğretmenlerinin empati, saydamlık, eşitlik, yeterlilik puan ortalamalarında görev süresi değişkenine göre anlamlı bir fark olduğu görülmektedir. Etkililik alt boyutu puan ortalamaları arasında ise görev süresine göre anlamlı düzeyde bir fark bulunmamıştır. Empati alt boyutu puan ortalamaları arasındaki farka ilişkin Mann Witney U sonuçlarına göre 6-10 yıl görev süresi olanların 1-5 yıl süresi olanlara göre empati puan ortalaması anlamlı düzeyde yüksektir. Ayrıca 20 yıl ve üzeri görev süresi olanların empati puan ortalaması 1 - 5 yıl olan öğretmenler ile 11-20 yıl olan öğretmenlerin puan ortalamalarına göre anlamlı düzeyde yüksek olduğu sonuçlarına ulaşılmıştır.

Saydamlık alt boyut açısından incelendiğinde Mann witney U sonuçlarına göre 6-10 yıl görev süresi olanların 1-5 yıl süresi olanlara göre saydamlık puan ortalaması anlamlı düzeyde yüksektir. Ayrıca 20 yıl ve üzeri görev süresi olanların saydamlık puan ortalaması 1-5 yıl olan öğretmenlere göre, 11-20 yıl görev süresi olan öğretmenlerin saydamlık puan ortalaması 1-5 yıl olan öğretmenlerin puan ortalamalarına göre anlamlı düzeyde yüksek olduğu sonuçlarına ulaşılmıştır.

Eşitlik alt boyutunda ise sadece 11-20 y1l görev süresi olan öğretmenlerin 1-5 y1l görev süresi olan öğretmenlere göre anlamlı düzeyde yüksek puan ortalamasına sahip olduğu bulunmuştur. Levent (2011), Nacar (2010) yaptıkları çalışmada öğretmenlerin eşitlik alt boyutunun mesleki tecrübeleri yönünden karşılaştırıldığında, öğretmenlerin eşitlik değerlerini anlamlı derecede yüksek olduğunu sonucuna ulaşılmıştır. Elde edilen bu sonuç çalışmayla paralellik göstermektedir.

Yeterlilik alt boyutu açısından bakıldığında 6-10 y1l ve 11-20 yıl görev süresine sahip öğretmenlerin puan ortalamalarının 1-5 yıl görev süresine sahip öğretmenlerin puan ortalamalarına göre anlamlı düzeyde yüksek olduğu görülmektedir. Bu sonuçlar öğretmenlerin mesleki kıdemlerinin artmasıyla birlikte iletişim becerilerinin geliştiğini göstermektedir.

Nacar (2010) ve Levent (2011) yaptıkları çalışmada öğretmenlerin iletişim becerilerinin mesleki kıdem ve yaş değişkenine göre farklılaştığı sonucuna ulaşmışlardır. Elde edilen bu sonuç araştırmadan elde edilen sonuçla paralellik göstermektedir.

Sınıf öğretmenlerinin birlikte çalışma yeterlilikleri puan ortalamaları arasında ise görev süresine göre anlamlı düzeyde bir fark bulunmamıştır. Arslan ve Sünbül (2006) ve Demirer (2014) yaptıkları çalışmada öğretmenlerin 
birlikte çalışma yeterliklerinin mesleki kıdem ve yaş değişkenine göre farklılaştığı sonucuna ulaşmışlardır. Elde edilen bu sonuç araştırmadan elde edilen sonuçla paralellik göstermektedir.

Sınıf öğretmenlerinin iletişim ve birlikte çalışma yeterlilikleri arasında anlamlı düzeyde olumlu bir ilişki olduğu sonucuna ulaşılmıştır.

\section{Öneriler}

Araştırmada ele alınmayan değişkenler ile iletişim becerileri ve birlikte çalışma yeterlikleri test edilebilir.

Erkek öğretmenlerin iletişim becerilerinin artırılması için bu konuda hazırlanacak seminerler, eğitimler verilebilir.

Şehirdeki okullarda görev yapan sınıf öğretmenlerine birlikte çalışma alışkanlığı kazandırmak adına çeşitli etkinlikler, kurslar düzenlenebilir.

Öğretmenlerin birlikte çalışma yeterliklerini yukarıya taşıyacak faktörler tanımlanmalıdır. Öğretmenlerin düşüncelerini rahatça ifade edebileceği birlikte çalışmayı özendirecek çalışma iklimi hazırlanmalıdır.

Ayrıca öğretmenlere birlikte çalışmada bulunmalarına yönelik teşvikte bulunulup ve ödüllendirme aracı geliştirilebilir.

\section{Kaynakça}

Arslan, C. ve Sünbül, A. M. (2006). Öğretmenlerin Birlikte Çalışma Yeterlilikleri. Osmangazi Üniversitesi Sosyal Bilimler Dergisi, 7 (1), 25-36.

Baltacı, A. (2018). Nitel Araştırmalarda Örnekleme Yöntemleri ve Örnek Hacmi Sorunsalı Üzerine Kavramsal Bir İnceleme. BEÜ SBE Derg.,7(1), 231-274.

Bulut, N. B. (2003). İlköğretim sınıf öğretmenlerinin iletişim becerilerine ilişkin algılarının çeşitli değişkenler açısından incelenmesi. Türk Ĕ̈itim Bilimleri Dergisi, 2(4), 443-452.

Çam, S. (1999). İletişim becerileri eğitimi programının öğretmen adaylarının ego durumları ve problem çözme becerisi algılarına etkisi. Türk Psikolojik Danışma ve Rehberlik Dergisi, 2(12), 16-27.

Çetinkanat, A.C. (1997). Öğretmenlerin İletişim Becerileri. 3. Ulusal Sınıf Öğretmenliği Sempozyumu, 23-24 Ekim, Adana, 17-26.

Çiftçi, S., Meydan, A., Koçyiğit,S. ve Kayılı,G. (2011). Sınıf öğretmenlerinin birlikte çalışma durumlarına ilişkin okul yöneticilerinin görüşleri. Selçuk Üniversitesi Ahmet Keleşoğlu Eğitim Fakültesi Dergisi, 32, 211224.

Çiftçi, S. ve Taşkaya, S. M.(2010). Sınıf Öğretmeni Adaylarının Öz Yeterlik ve İletişim Becerileri Arasındaki İlişki. E-Journal of New World Sciences Academy, 5 (3), 921-928.

Aydın, R. ve Nartgün, Ş. (2015). Öğretmenlerin, Örgütsel Sosyalleşme Düzeyleri ile Birlikte Çalışma Yeterlilikleri Arasındaki İlişki. Çağdaş Yönetim Bilimleri Dergisi, Sayı: 2(1), 9-24.

Demirer, S (2014). Öğretmenlerin Örgütsel Sosyalleşme ve Özdeşleşme Düzeyleri İle Birlikte Çalışma Yeterlilikleri Arasındaki İlişki, Yayımlanmamış Yüksek Lisans Tezi, ABANT İZZET BAYSAL ÜNIVERSITESİ Eğitim Bilimler Enstitüsü, Bolu.

Duman, B., Göçen, G. ve Duran, V. (2013). İlköğretim öğretmenlerinin kolektif yeterlik düzeylerinin çeşitli değişkenler açısından incelenmesi. Hacettepe Üniversitesi Eğitim Fakültesi Dergisi, Özel Sayı (1), 144155 .

Karasar, N. (2011). Bilimsel Araştırma Yöntemi (22. Basım). Ankara: Nobel Yayınları.

Nacar, F.S. (2010). Sınıf Öğretmenlerinin İletişim ve Kişilerarası Problem Çözme Becerilerinin İncelenmesi. Yüksek Lisans Tezi, Çukurova Üniversitesi/ Sosyal Bilimler Enstitüsü, Adana. 
Levent, B (2011). Sınıf Öğretmenlerinin Kişilik Özelliklerinin iletişim Becerilerine Etkisi, Yayımlanmamış Yüksek Lisans Tezi, Necmettin Erbakan Üniversitesi Eğitim Bilimler Enstitüsü, Konya.

Satman, C. (2013). Devlet Okullarında Görev Yapan Öğretmenlerin Ekip Çalışması Konusundaki Yaklaşımları, Ekip Çalışmasına İlişkin Motivasyon ve Doyum Düzeylerinin İncelenmesi, Yayımlanmamış Doktora Tezi, Ankara Üniversitesi Eğitim Bilimler Enstitüsü, Ankara.

\section{Extended Abstract}

The communication abilities of teachers in schools and the nature of collaboration behaviors are both interrelated and have a content that affects and affects each other. Therefore, effective communication makes it possible to work together, and collaboration also increases the effectiveness of communication. Considering these two phenomena that feed each other together makes this study important. it is expected to make the study more meaningful

\section{Problem Sentence}

The problem phrase of the study is "what is the relationship between classroom teachers ' levels of collaboration and communication skills?"designated as.

\section{Purpose Of Research}

The aim of this study was to examine the level of collaboration and communication skills of classroom teachers.

\section{Sub-Problems}

1. What is the level of interoperability and communication skills of classroom teachers?

2. Do classroom teachers ' collaboration skills and communication skills differ according to the gender variable?

3. Do classroom teachers ' ability to work together and communication skills differ depending on the variable where teachers work?

4. Do classroom teachers 'collaboration skills and communication skills differ according to the teachers' professional seniority variable?

5. Is there a meaningful relationship between classroom teachers ' competence to work together and their communication skills?

According to the findings from the analysis of the research data collected, the teachers of communication skills, empathy, transparency, equity, effectiveness and competence of the dimensions of the average is to be taken from the average of the values on the scale of the conclusion reached.

According to the results obtained from the analysis of the competence of classroom teachers to work together, it was concluded that the competence of teachers to work together was high.

Communication skills of the classroom teacher sub-dimensions, comparison by gender, empathy, transparency, equity, adequacy and sub-dimensions in terms of gender among the male teachers the female teachers, statistically significant difference in favor of women was found. In the lower dimension of effectiveness, no significant differences were found compared to the gender variable.

A significant difference in empathy, transparency, equality, effectiveness and competence sub-dimensions was found in comparing the sub-dimensions of classroom teachers ' communication skills according to the location variable performed.

The competence of classroom teachers to work together differs significantly in favor of teachers working in the village according to the location variable.

It seems that there is a significant difference in the average score of classroom teachers ' empathy, transparency, equality, competence compared to the duration of the task variable. There was no significant difference between the effectiveness sub-size score averages compared to the duration of the task.

There was no significant difference between the average score of classroom teachers ' competence to work together compared to the duration of the task. 
It was concluded that there was a significant positive relationship between the competence of classroom teachers to communicate and work together.

\section{References}

Communication skills and interoperability competencies can be tested with variables not addressed in the research.

In order to increase the communication skills of male teachers, seminars and trainings can be given to be prepared on this subject.

In order to give classroom teachers working in schools in the city the habit of working together, various activities and courses can be organized.

Factors that will increase the competence of teachers to work together should be identified. A working climate should be prepared that will encourage collaboration, where teachers can comfortably express their thoughts.

In addition, teachers can be encouraged to work together and a reward tool can be developed.

Qualitative and mixed research can be done on these issues.

Problems arising from the lack of communication skills in primary schools connected to the ministry can be identified and necessary policies can be developed for solutions to this.

In the study, classroom teachers working in primary schools affiliated to the ministry were studied. New research can be repeated with teachers working at other school levels associated with the ministry and in different branches. Or research can also be repeated with candidates for teachers in different programs of educational faculties.

In the study, the communication skills of teachers were examined in five dimensions (empathy, transparency, equality, effectiveness and competence), and each dimension was considered separately by developing different scales, which could lead to different results that this study failed to reveal. 